\title{
Mobilizing VAT Revenues in African Countries
}

\author{
Sijbren Cnossen ${ }^{a, b}$ \\ ${ }^{a} \mathrm{CPB}$ Netherlands Bureau for Economic Policy Analysis \\ P.O. Box 80501 \\ The Netherlands - 2508 GM The Hague cnossen@ese.eur.nl \\ ${ }^{b}$ University of Pretoria, Pretoria, South Africa
}

\begin{abstract}
Several African countries have to increase their tax revenues to finance human and economic development. General consumption taxes, such as VATs, are the preferred instrument for doing so, because they are less detrimental to growth than income taxes. To enable their use, VAT design has to be improved. Currently, many VATs are so riddled with exemptions and zero rates on domestic goods that they resemble extended excise tax systems, while the standard rate is mainly confined to luxury goods. VAT base-broadening would not only increase revenue, but also reduce the economic distortions and administrative complexities of most taxes.
\end{abstract}

JEL-Code: H210, H250.

Keywords: Africa, collection efficiency, tax effort, VAT. 
Africa is often called the most promising continent of the 21st century. Living standards are expected to rise considerably in tandem with sustained economic growth. ${ }^{1}$ But this is unlikely to come about without additional publicly-financed investment in education, health care, public utilities and transportation systems. Unfortunately, most government budgets are too small to make this possible. In more than half of all countries on the continent, tax revenue as a percentage of GDP (called the tax ratio) is around 15 or less, which is not enough to finance more human and economic development. Until recently, financial aid from developed countries could be used to finance public investment and shortfalls in current government budgets, but this source has largely dried up due to the recession in the industrialized world.

This means that domestic tax revenue mobilization is called for if economic development is to proceed. Whether or not tax ratios can be increased depends on each country's tax capacity - that is, the tax revenue (expressed as a percentage of GDP) that can be raised in light of the country's economic and institutional environment. To the extent that a country is not fully realizing its tax capacity, its tax effort - that is, the tax ratio as a fraction of tax capacity - is lower than 1 . The difference between 1 and the tax effort therefore indicates how much more a country can do to mobilize domestic tax revenue.

The tax capacities of several African (and other) countries have recently been calculated by Fenochietto and Pessino (2013), who use an econometric model to build a 'stochastic tax frontier' for panel data from 25 African (and 88 other) countries covering the period 19912012. Country-specific demographic, economic and institutional characteristics that may change over time are taken into account. The study finds a positive and significant relationship between tax revenue (including pension contributions) and the level of economic development (measured by per-capita GDP), trade (imports and exports, considered easy tax handles) and public expenditure on education (which facilitates compliance). By contrast, a negative relationship is found between tax revenue and changes in the consumer price index (expressing (un)certainty), the Gini coefficient (an unequal income distribution tends to hinder compliance), agricultural value added (a proxy for the difficulty of tax collection) and the corruption perception index (a proxy for the tax system's lack of operational quality).

Table 1 shows the tax ratios, tax capacities and tax efforts of 25 African countries calculated by Fenochietto and Pessino $(2013)^{2}$ and the author's guesstimate (derived on the basis of the same variables used by Fenochietto and Pessino) of the category of tax effort (low, medium or high) to which 20 other countries are likely to belong. In all, 17 out of 45 countries with a

\footnotetext{
${ }^{1}$ In a cautious assessment, Rodrik (2014) expects moderate and steady growth of perhaps as much as $2 \%$ per capita. He believes that the traditional engines behind rapid growth, structural change and industrialization still seem to be operating at less than full power.

${ }^{2}$ Resource-rich countries (Cameroon and the Republic of the Congo) are included in the analysis, but only for their tax revenue (without revenue from oil and mining) as a percentage of non-natural resources GDP.
} 
value added tax (VAT) can be classified as low-tax-effort countries, meaning that they collect two-thirds or less of the revenue that they can be expected to raise in view of their institutional and economic circumstances. In 20 other countries, the tax effort is labeled medium: the gap between tax effort and tax capacity is one-third to one-fifth of tax capacity. Eight countries exhibit a high tax effort. ${ }^{3}$ Malawi, one of the poorest countries in Africa, with a per-capita income of US\$700 (purchasing power parity), has a very high tax effort. Egypt, a middle-income country by African standards, with a per-capita income of US\$5,000, has a low tax effort.

\section{[here about table 1]}

The difference between the tax ratio and tax capacity represents the tax policy gap (exemptions and concessional rates) but not the compliance gap (evasion and inadequate enforcement), which is reflected in each country's proxies for the economic and institutional environment. This paper focuses on the policy gap of the VAT, ${ }^{4}$ often the most important source of tax revenue in African countries. In raising additional revenue, the VAT is generally regarded as an easier tax handle and less detrimental to economic growth than the income tax. ${ }^{5}$ VAT revenue enhancement should also make it possible to recover the loss of the revenue from import duties, which have to be phased out if closer economic integration and outward orientation, which promote growth, are to be pursued in line with the requirements of the World Trade Organization (WTO). ${ }^{6}$

The following sections review and discuss the structure, revenue performance and base erosion of the VAT systems in Africa and the shape of potential African VAT reform.

Although standard rates tend to be fairly high, the widespread practice of exempting or zerorating consumer goods (ostensibly, to mitigate the VAT's regressivity) erodes the revenue potential of most VATs. As a result, collection efficiencies (actual revenue over potential revenue, also called C-efficiency) tend to be low. The base erosion of the various VATs is examined in greater detail in section 3 , along with the distortions caused by concessional treatment and the unsuitability of the VAT to mitigate the burden on the poor. Section 4 argues that bold reform is called for if VATs are to be used to mobilize domestic tax revenue,

\footnotetext{
${ }^{3}$ The high tax effort in Lesotho, Namibia and Swaziland can partly be explained by the fact that the South African Revenue Service (SARS) collects the import and excise duties for these countries under the umbrella of the South African Customs Union (SACU).

${ }^{4}$ In various countries, the VAT is called goods and services tax (GST, for short) but, as is well known, this is just another name for the same type of taxation.

${ }^{5}$ Empirical evidence collected by Kneller, Bleany and Gemmell (1999), for instance, suggests that income taxes reduce the rate of economic growth whilst consumption taxes do not.

${ }^{6}$ Keen and Mansour (2010) argue that non-resource revenues were essentially stagnant in sub-Saharan countries between 1980 and 2005, although reductions in trade revenue have generally been largely offset by increased revenue from domestic sources. Further, Baunsgaard and Keen (2010) show that past replacement has been robust with regard to high- and, to a lesser degree, middle-income countries, but that the evidence for lowincome countries is flimsy. The authors (p. 573) conclude that their results suggest that perhaps only 'something like one-sixth to one-quarter of low-income countries has succeeded in substantially replacing lost trade tax revenues'.
} 
using as illustration the experience of four countries that are leading the way. The paper concludes with some general observations.

\section{$2 \quad$ African VAT systems at a glance}

For VAT purposes, African countries are best grouped by the Regional Economic Community (REC) to which they belong. Table 2 does so and provides details of the various VAT systems and information on their revenue performance.

\section{[here about table 2]}

\subsection{Survey}

In the past 25 years, 45 out of 54 African countries have adopted the VAT as their main broad-based consumption tax. ${ }^{7}$ Basically, two kinds of VAT have been introduced. The South African VAT (which closely resembles the broad-based, revenue-productive New Zealand GST) is found in the countries that are members of the South African Customs Union (SACU). The VATs in all other African countries are based on the European (EU) VAT, be it the anglo-, franco- or lusophone version. The EU VAT has more exemptions and differentiated rates than the broad-based, single-rate New Zealand GST and, hence, tends to be more complicated.

Most African countries introduced the VAT around the turn of the century, but some countries arrived much earlier on the VAT scene. ${ }^{8}$ The DR Congo and Swaziland converted their sales taxes into a VAT in 2012. The Gambia and the Seychelles followed their example in 2013, making them the latest members of the African VAT club. The year of introduction has some significance since it has been suggested that VATs (like wine) get better with age, presumably because tax administrations and taxpayers gain experience the longer the tax has been around (Ebrill et al., 2001).

The countries in table 2 are listed under the Regional Economic Community to which they belong. Four RECs can be considered more or less complete customs unions, which have abolished most intra-REC duties (but not necessarily non-tariff barriers) and adopted a common external tariff. These customs unions are the Southern African Customs Union

\footnotetext{
${ }^{7}$ The countries that have not yet introduced the VAT are Angola, the Comoros, Eritrea, Liberia, Libya, Nigeria, São Tomé \& Príncipe, Somalia and South Sudan. Although Nigeria calls its consumption tax VAT, in fact the tax is a gross-product type of sales tax, which does not permit a credit for the tax on investment goods and services, and provides export refunds, if at all, out of budgetary allocations rather than from gross VAT collections. Further, Egypt is a borderline case, because the taxation of services is not integrated with that of goods. Djibouti's VAT as a broad-based consumption tax is also suspect, since the threshold is very high (US\$278,000) and the indirect tax system is dominated by a multi-rate extended type of excise tax system.

${ }^{8}$ There may be some confusion about the exact date on which some countries introduced the VAT. Various African countries - for instance, Côte d'Ivoire - started with a manufacturers' sales tax using the tax credit mechanism (essential to a VAT) to eliminate tax-on-tax or cascading effects. They called these taxes VAT from the beginning, although the wholesale and retail stages were included at a later date.
} 
(SACU), the East African Community (EAC), the Economic and Monetary Community of Central Africa (CEMAC, after its French name Communauté Économique et Monétaire de l'Afrique Centrale) and the Economic and Monetary Union of West Africa (UEMOA, after its French name Union Économique et Monétaire Ouest Africaine).

Further, there are three free trade areas in which intra-REC duties have been abolished on many but not all products while country-specific external tariffs are still being maintained. The free trade areas are the Southern African Development Community (SADC, which includes the SACU countries), the Economic Community of West African States (ECOWAS, consisting of the UEMOA REC and the West African Monetary Zone (WAMZ)) and the Common Market for Eastern and Southern Africa (COMESA, which is not shown separately in table 2 since it overlaps with six other RECs). ${ }^{9}$ Finally, two RECs are 'not notified agreements' to the World Trade Organization - namely, the Union Maghreb Arabe (UMA, which is not a member of the African Economic Community) and the Intergovernmental Authority on Development (IGAD), both of which are little more than talking forums.

The RECs actively discuss the alignment of their member countries' tax systems. Some RECs even have nearly-identical VATs. The VATs in the SACU countries, for instance, are all modeled on the South African example. The VATs in the CEMAC and UEMOA RECs closely resemble the French VAT and are based on common regulations. Similarly, the VATs in the UMA are (old) shoots from the French VAT tree. Further, the EAC countries are aligning their VATs in the quest to establish a common market. Although VAT harmonization has its advantages, it also tends to institutionalize existing shortcomings, as has happened in the EU with the promulgation of the VAT Sixth Directive in 1977. Experience has shown that the Directive is exceedingly difficult to adapt to new economic and institutional developments or best practices in other countries, since this requires the unanimous consent of all 28 member states. ${ }^{10}$

\section{$2.2 \quad$ VAT systems}

The essential features of the VAT systems in African countries are reflected in the rate structures and the tax bases. Table 2 shows the standard rate and the reduced rate(s), including the zero rate, if applied, on domestically-consumed products. In most countries, the standard VAT rate is around $18 \%$. Djibouti has a low VAT rate of $7 \%$, and a high rate of $20 \%$ is found in Madagascar and Morocco. As one would expect, the standard rate tends to be somewhat lower in SACU countries, which have broad-based VATs.

\footnotetext{
${ }^{9}$ In 1999, COMESA teamed up with ECOWAS and SADC to form the African Economic Community (AEC). The (ambitious) goals of the AEC are a continent-wide customs union by 2019 and a common market by 2023 , followed by an economic and monetary union in 2028.

${ }^{10}$ For a succinct assessment of the shortcomings of the EU VATs, see Cnossen (2003). For a dismal picture of the Dutch VAT reflecting the long shadow of the EU Common Directive, see Bettendorf and Cnossen (2014).
} 
The coverage of the lower rate is denoted either by listing the items taxable at that rate or, more often, by using the annotations 'few', 'some', 'various' and 'many' goods and services to indicate its extent. The zero rate (other than on exports), mainly applied to unprocessed foodstuffs and agricultural inputs, is particularly prevalent in countries with anglophone taxing traditions (the UK and Ireland, as well as Australia and Canada, zero-rate all or various specified foodstuffs), but a zero rate is also found in Burundi, the Congo, Equatorial Guinea and Mozambique. Generally, countries with francophone and lusophone taxing traditions do not have a zero rate, but instead exempt basic foodstuffs. This greatly reduces the number of VAT registrations and refunds, which require careful monitoring. In the case of reduced but positive rates, moreover, these countries tend to heed the butoir rule, which prescribes that rates should not be set so low that almost invariably a refund of prior-stage VAT becomes due. Finally, very few countries have higher-than-standard rates and those that do (see footnote a in table 2) confine their coverage to one or two items that should be subject to (a higher) excise tax. ${ }^{11}$

As regards VAT bases, nearly all African VAT statutes list the same 'standard' exemptions as found in the EU's Sixth Directive for health care, education, social, cultural, postal and financial services, immovable property (except if newly created), insurance, gambling, public broadcasting and 'out-of-scope' governments. ${ }^{12}$ Hence, these are not shown in table 2 . In addition, however, African countries exempt many 'non-standard' items, such as basic foodstuffs, medicines and pharmaceutical products, newspapers and books, water, electricity, public transportation, feed, seed, fertilizer, agricultural implements, petroleum products and handicrafts. The non-standard exemptions seriously erode the VAT base and distort regional (and international) trade, because of the 'hidden' VAT on inputs for which no credit or refund is provided at export. In table 2, the extent of these exemptions is denoted by 'few' (some enumerated basic foodstuffs and public transportation), 'some' (more food items and some public utilities), 'various' (most unprocessed foods, agricultural inputs, medical goods, newspapers and utilities) and 'many' (all unprocessed foods, agricultural inputs, medical goods, utilities, print and fuel).

Along with the zero rates on domestically-consumed products, the non-standard exemptions turn many VATs into proverbial Swiss cheeses - more holes than substance. As a result, the VATs become what may be called extended excise tax systems. After all, in practice, it may not make much difference whether goods are specifically enumerated as being taxable (the

\footnotetext{
${ }^{11}$ Instead of higher rates, many countries, particularly those with anglophone taxing traditions, try to improve the progressivity of their indirect tax systems by imposing separate excises on a large number of luxury goods. SACU and IGAD countries are examples of this practice. Cnossen (2004) argues that this is largely window dressing.

${ }^{12}$ The use of 'standard exemptions' in EU VAT jargon (see, for instance, OECD (2012)) is an utter misnomer, since 'standard' implies 'something established by authority, custom, or general consent as a model or example' (Merriam-Webster, International Dictionary). Surely, this meaning does not apply to the VAT exemptions in the EU, which are anything but a model or example to emulate, although many countries have copied them. Note that some of the exempt services in the Sixth Directive, particularly gambling, insurance and fee-based financial services, are taxed under the VATs in the SACU countries.
} 
excise tax approach) or whether a large number of specifically-enumerated goods are exempted or zero-rated (the African VAT approach). Economically, the non-standard exemptions give rise to indeterminate variations in effective VAT rates depending on the ratio of VAT on taxable inputs to tax-exclusive consumer prices, while the zero rates greatly complicate the VAT administration. Last but not least, the exemption or zero-rating of many products disproportionately consumed by the poor effectively turns the standard rate into a tax on luxury goods and services.

As shown in table 2, the VAT registration threshold varies widely in African countries, although the low-rate turnover taxes in some countries on small firms not registered for VAT purposes mean that small businesses still pay tax over and above the VAT on inputs. The UEMOA countries, Chad and Mauritania have a lower threshold for service providers, presumably because more value is added at the business level than is the case for goods, which would not be taxed under the regular threshold. Unusually low thresholds are found in Algeria and Cabo Verde. Egypt and Morocco have higher thresholds for the distributive trade. High VAT thresholds tend to save on compliance and administration costs, but induce small businesses to split up operations. Perhaps South Africa's threshold of US\$93,000 is a good example of keeping the small fish out of the VAT net, so that administrative efforts can be focused on enforcing the compliance of large firms. The country reinforces this focus by disallowing the registration of firms with a turnover of US\$5,000 or less.

This broad and perhaps somewhat perfunctory review sets the stage for a closer look at the revenue importance of the VATs in African countries.

\section{$2.3 \quad$ VAT revenue performance}

VATs, trade taxes and excise duties tend to account for some two-thirds of total tax revenue in low-income African countries (Moser, 2011), which reflects the ease with which the respective tax handles can be exploited at borders and at the level of large domestic taxpayers. ${ }^{13}$ Half of VAT revenue tends to be collected at the import stage and most of the remainder from producers of traditional excisable products. ${ }^{14}$ As shown in table 2, 24 out of 40 countries for which reasonably reliable data are available collect $25 \%$ or more of total tax revenue in the form of VAT. ${ }^{15}$ This relatively important contribution, however, should be put

\footnotetext{
13 The seminal work on the role of tax handles in economic development is Musgrave (1969).

${ }^{14}$ Ebrill et al. (2001, p. 50) report the following figures on VAT on imports relative to VAT revenues for African countries: Benin 70\%, Burkina Faso 51\%, Cameroon 43\%, Gabon 51\%, Ghana 50\%, Guinea 62\%, Mauritania 66\%, Mauritius 60\%, Togo 68\%, Uganda 58\% and Zambia 67\%. Although these figures are rather old, there is no reason to assume that current data differ significantly. For Uganda, the International Monetary Fund (2005) concluded that, to a large extent, the VAT and the excises were border taxes since approximately two-thirds of the combined revenue was collected on imported goods and the remainder on a few domestic products manufactured by some 10-12 firms.

${ }^{15}$ Ignoring countries for which revenue data are not available or are incomplete: Burundi, DR Congo, Gambia, Djibouti and Sudan. The data for a few other countries may also be suspect, particularly if VAT (and excise tax) collections have not been properly separated out from import duty receipts.
} 
into the context of generally low overall tax ratios and VAT being collected predominantly at import stages.

While revenue shares are valuable indicators of the revenue performance of VATs, they do not explain differences in VAT performance. For this purpose, the tax literature - notably, Ebrill et al. (2001) and Keen (2013) - has developed the concept of VAT collection efficiency (or VAT C-efficiency, for short), which can be related to the structural characteristics of the VAT (exemptions, reduced rates, thresholds) and various economic and social factors such as those used by Fenochietto and Pessino (2013) and others. ${ }^{16} \mathrm{C}$ efficiencies measure a country's VAT performance as the ratio of the revenue actually collected to the potential revenue found by applying the standard rate, $\tau$, to final consumption expenditures (net of VAT) shown in national accounts. ${ }^{17}$ In other words:

$$
\text { VAT C-efficiency }=\frac{\text { Actual VAT revenue }}{\tau * \text { Final consumption }} \text {. }
$$

Accordingly, the VAT's C-efficiency indicates what percentage of final consumption expenditure is collected by each percentage point of the standard VAT rate. Obviously, Cefficiency has unit value for a uniform tax on all consumption. The difference between this unit value and the actual C-efficiency represents the VAT that is not collected on account of exemptions (net of the VAT on inputs), zero rates (other than on exports) and lower-thanstandard rates, as well as shortcomings in compliance and administration. The loss of VAT revenue attributable to exemptions and zero or lower-than-standard rates is called the policy gap, while the VAT's operational shortcoming is referred to as the compliance gap. ${ }^{18}$

Table 2 (third column from the right-hand side of the table) shows the C-efficiencies of African countries with a VAT. The efficiencies range from a low of 0.11 in Côte d'Ivoire, Ethiopia and Niger to highs of 0.67 in South Africa and 0.87 in the Seychelles. In two-thirds of countries, the C-efficiency is less than 0.50; in 17 countries, it is less than 0.35; and the average for all countries is 0.39 . Not surprisingly, in view of their broad VAT bases, SACU and UMA countries have high C-efficiencies (comparable to those calculated for most

\footnotetext{
${ }^{16}$ Ebrill et al. (2001, table 4.2) report on multivariate regressions, using a cross-section of (at most) 89 developed and developing countries. The dependent variable in their analysis is the (ln) ratio of VAT revenue to private consumption. They find that this measure is positively related to the (ln) standard rate, the country's openness (trade as a percentage of GDP) and the literacy rate.

${ }^{17}$ Preferably, final consumption should be aggregated over households, governments and non-profit organizations. For lack of data, however, the C-efficiencies in this paper do not include government consumption expenditures in the denominator.

${ }^{18}$ Unfortunately, separate data for the policy and compliance gaps in African countries are not available. For EU countries, Keen (2013, p. 423) concludes that policy gaps (exemptions and rate differentiation) are in almost all cases far larger than compliance gaps, but it is unlikely that this is the case in most African countries.
} 
European countries), while the VATs in CEMAC and various UEMOA countries perform poorly. $^{19}$

Since consumption data may be less reliable than GDP data for some countries, some authors prefer to express VAT revenue performance as actual VAT collections over GDP divided by the standard rate. In the tax literature, this ratio is called the VAT's productivity. It indicates the percentage of GDP that is collected by 1 percentage point of the standard rate. Table 2 (penultimate column) lists the VAT productivities of African countries. By this measure, 30 out of 40 countries collect less than $0.4 \%$ of GDP for every percentage point of the standard rate; the average for all countries is $0.3 \%$.

As can be expected, VAT productivity and VAT C-efficiency are closely correlated (the correlation coefficient is 0.91). VAT's C-efficiency is simply its productivity divided by the share of consumption expenditures in GDP. Unlike the unity benchmark for the C-efficiency, there is no specific benchmark for VAT productivity, although a figure below the average $(0.30 \%$ in Africa, low in itself) indicates that there are wide policy and/or compliance gaps.

Figure 1 shows the VAT productivities and C-efficiencies for 40 African countries for which data are available (see table 2). The figure clearly demarcates countries with a C-efficiency of, say, 0.40 or higher and productivity of better than $0.30 \%$ from countries whose Cefficiency and productivity are lower.

\section{[here about figure 1]}

VAT productivity in African countries is on average distinctly lower than that in other regions of the world, whether the Middle East, the Western Hemisphere, Asia and the Pacific, or the European Union (WoldeMariam, 2010). Accordingly, C-efficiencies should be lower, too. This may be attributable to economic factors (such as the degree of monetization), the share of agriculture (perforce exempted) in GDP, lack of administrative effectiveness, or a combination of these factors. No doubt, however, the low C-efficiencies should also be

\footnotetext{
${ }^{19}$ Similar to Ebrill et al. (2001), CPB’s Leon Bettendorf, at the author's request, has done a multivariate regression analysis for 35 of the countries shown in table 2. He found a significant coefficient for each of the variables (standard rate, exemption, threshold) that represent the VAT structure. First, a rise in the standard rate by 1 percentage point is seen to decrease C-efficiency by 3.4 percentage points, presumably because evasion increases. Secondly, efficiency is lower in 20 countries that apply 'many' non-standard exemptions (see table 2) than in other countries, while the opposite is found for six countries that limit the use of non-standard exemptions (denoted by 'few' and 'some' in table 2). This result expands on Ebrill et al.'s (2001) analysis, the data set for which did not contain the extent of exemptions. Thirdly, efficiency is negatively related to the size of the threshold (for selling goods, and measured relative to per-capita GDP as in Ebrill et al. (2001)). An increase in the threshold by one standard deviation ( $0.6 \%$ of GDP per capita) can be associated with an 8.1 percentage point lower efficiency. This result, perhaps not surprisingly in view of the relatively high thresholds in most African countries, again contrasts with Ebrill et al.'s (2001) finding that the threshold never proved significant.
} 
attributed to the tax policy gap - that is, the myriad exemptions and zero rates on domestic products. $^{20}$

To get a grip on the prevalence of VAT base erosion in African countries, this section starts by investigating the extent of the non-standard exemptions and zero rates on domestic goods and services in individual countries. ${ }^{21}$ It then highlights their distortionary nature and points out that exemptions and zero rates are ill-targeted instruments to mitigate the tax burden on lower-income groups.

\subsection{Overview of exemptions and zero rates}

Table 3A lists the exemptions of unprocessed foodstuffs, agricultural inputs, medical supplies, utilities, print, fuel, and some other goods and services in Africa on a country-bycountry basis. Table 3B does the same for the zero or positive but reduced rates on these items. The information in the tables can be summarized as follows:

\section{[here about tables $3 A$ and $3 B$ ]}

- Basic foodstuffs, generally unprocessed, are widely exempted in countries with French taxing traditions, while countries with Anglo-Saxon taxing traditions tend to zero-rate unprocessed foodstuffs. Often, the favorably-treated items are enumerated, particularly in SADC countries. Like most continental European countries, various CEMAC and UMA countries apply a positive reduced rate.

- Many SADC and EAC countries also apply a zero rate to agricultural inputs (feed, seed, fertilizer, but sometimes also machinery); other countries tend to exempt agricultural inputs (which, effectively, may imply little or no VAT if the inputs are imported). Again, UMA countries levy a reduced rate.

\footnotetext{
${ }^{20}$ It should be emphasized that the insights gained from this kind of analysis should not be overestimated. Errors in the measurement of consumption data in countries with large subsistence sectors may skew the results, as may errors in the classification of revenues as import duties instead of VAT or vice versa. Delays in or, worse, the denial of VAT refunds at export, prevalent in many countries, could bias the results significantly, as could presumptive assessments in lieu of proper accounting for VAT on sales and purchases. In short, a great number of large and small errors, intentional or inadvertent, could influence the results. See Martinez-Vazquez and Bird (2011) and Keen (2013) for wide-ranging discussion and analysis of these aspects.

${ }^{21}$ Standard exemptions are not dealt with in this paper. Gambling, property and casualty insurance, and feebased financial services can readily be taxed under the VAT, as shown by the SACU experience. There is also an emerging consensus that health care and education should be brought into the VAT base, but it is unlikely that this would raise any additional net revenue (although doing so would reduce distortions) if the subsidies for these services would have to be increased.
} 
- Medical supplies (pharmaceuticals, medicines) are zero-rated in SADC and EAC countries, but most other countries exempt them or apply a reduced rate. Often, the concessionary treatment extends to medical equipment.

- One or more utilities (water, electricity, natural gas, postal services, telecommunications, public transportation) are exempted in most countries, but some apply a zero or reduced rate. A basic, volume type of exemption for water and electricity is provided under the VATs in Benin, Cameroon, the Central African Republic, Chad, the Congo, Guinea, Madagascar and Senegal.

- Newspapers and periodicals are sometimes zero-rated (after all, they must spread the good news about the VAT) or, more often, exempted. In many cases, the exemption extends to school books or all printed materials.

- Fuel is zero-rated in SACU countries and exempted in some other SADC and most EAC countries. Many countries exempt or apply a reduced rate to kerosene, which is widely used by lower-income groups for heating and cooking purposes.

- Other goods and services that are sometimes zero-rated or exempted include building materials, (low-income) housing, transportation, admissions, entertainment, gambling, tourism, and machinery and equipment for agriculture, industry and mining.

\subsection{Economic distortions and administrative problems}

Exemptions distort consumer and producer choices, discriminate against exports, favor imports, increase administrative complexity and promote tax avoidance. The most important effects are now discussed. ${ }^{22}$

First, because the VAT on taxable purchases cannot be credited (washed out) against the VAT on output, businesses supplying exempt goods and services tend to substitute these purchases by lower-taxed or non-taxable goods and services. In other words, the exemptions distort input choices. Moreover, if the VAT charged on supplies to exempt entities cannot be passed on, suppliers are faced with a reduction in factor rewards. The distortionary effects of exemptions will not be confined to the exempt entity itself, but will tend to work their way through the entire production-distribution chain. Invariably, the effects are capricious and indeterminate regarding final prices and rewards of production factors.

Secondly, exempt entities will try to avoid the tax on taxable purchases by performing various activities themselves that they would otherwise procure at lower pre-tax cost from third parties. In doing so, they avoid the VAT on the labor element of the self-performed activity. Administrative, IT, laundry, cleaning, catering and safety-provision services are

\footnotetext{
${ }^{22}$ See Ebrill et al. (2001), on which this discussion draws.
} 
examples of this form of uneconomical integration. Naturally, the incentive to 'do it oneself' will be greater for purchases with highly-taxed inputs.

Thirdly, exports will be hampered, because the prices of goods and services that have elements of unrefunded VAT from inputs of exempt entities in them and the prices of exempt goods and services harm the competitive position of exports in world markets. Exemptions of financial services and insurance, for instance, violate the destination principle (imports taxed, exports free of tax), because the supplying firms are stuck with the VAT on their inputs, which increases their export prices or reduces factor rewards. Further, firms will tend to import exempt services if these are not subject to tax abroad or if the VAT is refunded at export by foreign VAT administrations.

Fourthly, exemptions will induce interest groups to push for an extension of exemptions to suppliers and customers of exempt entities. Even if the reach of these interest groups is limited (because, say, the VAT has been harmonized with neighboring countries), they can still argue for favorable interpretations and applications that expand the effective scope of the exemptions. Exemptions also form an incentive to avoid the VAT - for instance, by converting the (exempt) lease of immovable property into an agreement for the (taxable) storage of goods, so that the VAT-liable purchaser can credit the input tax against the VAT on his own sales. In addition, the correct attribution of the VAT on inputs to taxable and exempt supplies, when required, is an important bone of contention between exempt entities and VAT administrations. An example is the provision of taxable accounting and advisory services by exempt banks.

Last but certainly not least, leaving 'non-commercial' activities of governments 'out of scope’ should distort competition because governments can offer their goods and services that are not pure public goods at a lower VAT-inclusive price than private suppliers. The EU Common Directive, for instance, mentions a number of goods and services that should always be taxed, but various services that can be equally well performed by the private sector remain out of scope. Municipal garbage collection is one of the standard examples.

It should be noted that the distortions and complexities of exemptions at intermediate stages of production and distribution are arguably worse than those with regard to exemptions of, say, unprocessed foodstuffs sold by exempt (small) farmers (which may have to be exempted on administrative and political grounds), because the former are likely to involve more noncreditable input VAT.

\subsection{Can VAT's regressivity be mitigated?}

Most non-standard exemptions and zero rates, particularly those on domestically-sold foodstuffs, have been introduced in attempts to mitigate the VAT burden on low-income households. But how much do these households benefit from the concessionary treatment of particular goods and services? 'Not very much' is the conclusion of various VAT burden 
distribution studies. ${ }^{23}$ In monetary terms, higher-income groups appear to benefit most from the concessionary treatment of food. South Africa's Katz Commission (1994), for instance, estimated that only $18 \%$ of the benefit of zero-rating 19 basic foodstuffs ${ }^{24}$ and kerosene went to the poorest households. In Rand terms, the rich benefited six times more from zero-rating than the poor did. The Commission pointed out that the full taxation of basic foodstuffs would raise an amount of revenue far in excess of what would be needed to compensate the poor for the VAT they would have to pay if the zero-rated items were fully taxed. On the basis of its findings, the Katz Commission (1994, p. 127) concluded, therefore, that 'providing relief to the poor through exemptions and VAT zero rating is likely to be both unsound tax policy and ineffective social policy'. ${ }^{25}$

The findings of the Katz Commission were confirmed by Go et al. (2005) and by a thorough recent study by the National Treasury (2011) of South Africa. The latter study calculated (1) the share of VAT savings accruing to different expenditure groups regarding goods and services that are currently zero-rated or exempt and (2) the share of VAT paid by different expenditure groups in respect of various standard-rated goods and services for which a zero rate had been requested by interest groups. The results, shown in table 4, leave little doubt that zero-rating is not the way to go. The results can be summarized as follows:

\section{[here about table 4]}

- With the exception of maize (meal), bread flour and maize rice, the share of VAT savings attributable to zero-rated foodstuffs rises sharply as expenditure increases across the groups. Clearly, higher-expenditure groups benefit disproportionately from the zero rate on foodstuffs. This is also true for expenditures on cooking oil and paraffin (kerosene), which tend to be major expenditure items in most household budgets. The tax treatment of kerosene is of particular interest since its use generates negative externalities in the form of $\mathrm{CO}_{2}$ emissions, which makes zero-rating difficult to justify.

- The same regressively-distributed VAT benefit pattern is found for exempt public transport, regardless of the mode of transport. According to the National Treasury (2011, p. 150), the blanket exemption of public transport may even have increased the VAT's regressivity, as 'the more affluent using mainline passenger transport provided by luxury coach transport and touring operators also enjoy the benefits of the

\footnotetext{
${ }^{23}$ See Ebrill et al. (2001). VAT burden distribution studies are rare outside South Africa but, for Tanzania, Mugoya (1998) argued that the preferential treatment of foodstuffs did not make the country's VAT progressive, while it greatly eroded its revenue performance.

${ }^{24}$ See Section 11(1)(j) of the South African VAT Act. Originally, only brown bread and maize meal were zerorated, but in 1992 and 1993, following extended public protests, various other essential foodstuffs were added to the zero-rate list.

${ }^{25}$ For an analysis of the Commission's findings and information on the situation in other countries, see Cnossen (2004), who also points out that regressivity/progressivity should be considered for the tax system as a whole, not for VAT in isolation.
} 
exemption'. Further (p. 170), 'uncertainty often exists regarding who must be the fare-paying person or whether an exempt transport service or a standard rated renting of a vehicle is involved'.

- Higher-expenditure groups also benefit disproportionately from the exemption for education. Administrative complications arise when exempt institutes of higher learning are also engaged in taxable activities, such as research and the sale of books, whose taxation requires the apportionment of input tax. The National Treasury (2011, p. 170) opines that 'it is often not clear whether a certain service involves the supply of education or research, or whether a specific supply is "necessary for and subordinate and incidental to" the supply of educational services', and thus whether it qualifies for the exemption. Full taxation and increased targeted subsidies may be a better alternative.

Similar observations can be made regarding goods and services that are currently standardrated but that might qualify as 'merit goods', such as water, electricity, health care, books, journals and cultural events, whose intrinsic value may be underestimated by consumers. Their purchase should therefore be stimulated by governments, the argument goes - for example, by not levying VAT on them.

- Similar to foodstuffs, not taxing water and electricity would disproportionately benefit higher-expenditure groups, as shown in table 4. As the National Treasury (2011, p. 150) observes, 'the affluent will merely pay less for the large volumes of [zero-rated] electricity or water used for luxuries such as using electricity for dishwashers, air conditioners, fridges and other electrical appliances and using [zero-rated] water to fill swimming-pools, for dishwashers, automatic washing machines, saunas and watering their gardens'. Further, a social exemption for water and electricity, as found in various francophone countries, does 'not take into account the household structure of poorer families, where various generations, extended family and even friends are forced to stay under one roof. Their combined electricity consumption for basic use of appliances could equal or even exceed the use by an affluent couple, living in an upmarket residence using luxury appliances'. Finally, the basic exemption can easily be abused - for instance, by installing two meters in what is essentially one dwelling.

- The same observation applies to the VAT benefit distribution if no (input) tax were levied on medicines and health services. The poor derive limited benefits from preferential VAT treatment, because most medical products are largely unaffordable or of a low priority to these groups and zero-rating would not save these people the VAT if they can access medical services and medicines free through the public health system. Again, taxation and targeted subsidies, as are present practice in South Africa, do a better job in reducing distortions and administrative complexities whilst ensuring that the poor receive adequate medical care.

- Reading materials, too, are income-elastic items of consumption. Books, newspapers and journals are mainly bought by the affluent; the poor in South Africa prefer 
watching television to reading. Currently, books and other printed or electronic media that are supplied as part of educational services and that are covered by school or tuition fees are exempt from VAT. It is often argued that the taxation of books amounts to a tax on knowledge, but, according to the National Treasury (2011), the relatively low book penetration in South Africa has its origins primarily in low levels of literacy and generally poor reading skills - in other words, in the failures of the education system.

In reviewing these arguments in the South African context, the Katz Commission (1994) estimated that the revenue forgone on account of zero-rating amounted to nearly $10 \%$ of total VAT collections. In other words, the standard rate (12\% at that time) could be lowered by around 1.1 percentage points and raise the same amount of revenue if essential foodstuffs were taxed at the standard rate. ${ }^{26}$ In a similar vein, the National Treasury (2011, p. 116) estimated that social grants could be increased by $11 \%$ if zero-rating were abolished. In practice, South Africa's high registration threshold of US\$93,000 is another way to reduce the VAT burden on basic foodstuffs, because food products from small exempt farms traded through small exempt retail outlets do not enter the VAT base. Last but not least, zero-rating and exempting goods and services generate problems of definition and interpretation, create opportunities for evasion and exacerbate administrative control problems. Interestingly, South Africa counters the refund problem by disallowing the registration of firms with a turnover of US\$5,000 or less. Of course, this practice is at odds with the zero rate's objective.

\subsection{Zero-rating or exempting petroleum products and capital equipment}

Two items not shown in table 4 that are also zero-rated or exempted in SACU and other countries are petroleum products and, much more widely, agricultural and industrial capital equipment.

- It is difficult to find a justification for leaving petroleum products out of the VAT base. In many countries, the reasoning is that since an excise is levied on these products, applying the VAT would be tantamount to double taxation. But this confuses objectives and instruments. The objective of the excise is to account for the (substantial) external costs that attend the use or consumption of petroleum products. These costs should be internalized in price; they are not different from, say, production or distribution costs. As a revenue instrument, the VAT then should be imposed on the excise-inclusive price of petroleum products so that relative prices vis-à-vis other taxable goods and services do not change.

- The concessionary treatment of agricultural inputs is also problematic. Admittedly, zero-rating or exempting seed, feed, fertilizer, pesticides and equipment ensures that

\footnotetext{
${ }^{26}$ Here and elsewhere, it is assumed that changes in the VAT's rate or coverage do not involve behavioral changes.
} 
little non-creditable input VAT enters into the price of agricultural products when marketed by exempt farmers and subsequently sold through taxable distribution channels. If taxed, it would be possible to wash out the input VAT by allowing taxable purchasers of farm produce a presumptive VAT credit approximately equal to the input VAT borne by exempt farmers. This rough-and-ready approach is used in EU member states that exempt the agricultural sector. Zero-rating seems better targeted and easier from an administrative point of view, except for dual-use goods, such as various agricultural implements and tractors, which can also be used for taxable purposes. ${ }^{27}$

- It is fairly common in African countries to exempt industrial machinery and equipment from VAT, often at the import stage. Of course, this infringes the integrity of the VAT since end-use exemptions have to be monitored. However, exemption has the advantage that refund problems do not arise in the case of businesses that are in excess credit situations, because they start up operations, are seasonal or export their output. Taxation without a full credit or delayed refund of input VAT is tantamount to a tax on investment. A much better alternative would be to apply a reverse charge mechanism at import, which would not involve cash-flow problems.

- Finally, nothing can be said in favor of zero-rating or exempting building materials, admissions to organized cultural events and gambling, and little for the concessionary treatment of tourism. ${ }^{28}$

\section{Countries that have led the way in bold VAT reform}

The previous section showed that the need to improve VAT performance in order to increase revenue calls for a bold round of base-broadening reform in various African countries. Even countries whose performance is better than average can still improve the quality of their VATs through base-broadening. Fortunately, some countries have already led the way by completely revamping their VAT legislation and other countries are in the process of doing so, not an easy task since it has been observed that mistakes made at introduction are hard to undo (Keen, 2009). Generally, there is much to be learned from the SACU countries, which have had a broad-based, neutral VAT, inspired by the New Zealand example, from the beginning, although they trouble their VATs with a zero rate on various basic foodstuffs.

Four countries can be singled out for boldly reforming their deficient VATs. Benin and Senegal revisited their original VAT as early as 1991, Kenya followed suit in 2013 and Tanzania is now reforming its VAT. Benin and Senegal replaced their multi-rate exemptionridden VATs, levied at the manufacturing stage, by a broad-based, single-rate VAT in

\footnotetext{
${ }^{27}$ Keen (2008) argues that agricultural inputs should be taxed as a way to secure some revenue from the sector, which tends not to be subject to the income tax either.

${ }^{28}$ But for arguments to treat tourism leniently, see Ebrill et al. (2001, p. 73).
} 
1991. ${ }^{29}$ Until 2013, Kenya had a very narrow-based VAT with numerous exemptions and a zero rate on agricultural inputs, medical goods, print, petroleum products and various other goods and services, as well as a lower-than-standard rate on electricity. The country undertook a bold base-broadening reform in 2013, which in turn is now being emulated by its neighbor, Tanzania.

Details of the reformed VATs in these countries are shown in table 5. Basically, all four countries retained all standard exemptions (not shown in the table) for health care, education, social and financial services, gambling and public broadcasting. Commendably, Kenya limits the application of some of the standard exemptions - for example, education by prescribing that 'the exemption does not apply in respect of business or user training and other consultancy services designed to improve work practices and the efficiency of an organization'. Further, stage plays and cultural performances are only exempted if conducted by educational institutions. Interestingly, following the South African example, Tanzania intends to tax fee-based financial services. Unlike South Africa, gambling and property and casualty insurance retain their exempt status.

\section{[here about table 5]}

The most notable feature of the VAT reforms in Kenya and Tanzania is the abolition of the zero rate on domestically produced and consumed foodstuffs and various other goods, and its replacement by an exemption of specifically-enumerated foodstuffs, features that are also found in Benin and Senegal. Presumably, monitoring and enforcing the application of the zero rate drew valuable administrative resources away from more lucrative revenuegenerating VAT audit activities. The zero rate, as discussed above, did little more than an exemption of agricultural and fishing products would do in terms of mitigating the VAT burden on lower-expenditure households.

Further, agricultural inputs in Kenya are now exempted rather than zero-rated. Unfortunately, Tanzania proposes to continue its zero rate on domestically-produced agricultural inputs (and medicines), although this confuses VAT's revenue role with the protectionist function of the import tariff. Probably, it would be better to exempt these inputs, although zero-rating removes the discrimination in favor of imported capital equipment if they are exempted. Monitoring the exemption for tractors used for agricultural purposes will be difficult.

Medicines are exempted in all four countries, but only if sold for therapeutic or prophylactic use, which appears to exclude over-the-counter pharmaceutical products. Again, Tanzania burdens its VAT administration by requiring it to monitor the end-use exemption of packaging goods for pharmaceutical products. In Kenya, the social tranche for electricity consumption was abolished, as was the exemption for newspapers and books, which

\footnotetext{
${ }^{29}$ See Ebrill et al. (2001, p. 70), who note that the UEMOA Council of Ministers adopted a directive agreeing on a single-rate VAT (in the 15-20\% range) with limited exemptions (provided in a list of the UEMOA Commission) to be adopted by member countries by 2002.
} 
Tanzania seems to be keeping (as do Benin and Senegal). All four countries also retain the exemption for passenger transportation. As noted above, South Africa's National Treasury (2011) frowns upon these exemptions.

Kenya, Senegal and Tanzania retain the exemption for specified (imported) capital goods, although a better alternative would have been to apply a reverse charge at the import stage. Kenya is phasing out its zero rate for petroleum products but Tanzania intends to transform it into an exemption. Full taxation and adjustment of the excises (so that the total tax burden does not change) would be a better alternative.

Most of these changes are laudable improvements over the previous situation. They should boost revenue (the corresponding revenue figures are not yet in for Kenya and Tanzania). Last but not least, the much broader VATs and the elimination of special rates should make it easier to administer and comply with the tax.

\section{$5 \quad$ Concluding thoughts}

The pernicious economic and administrative effects of VAT exemptions have been thoroughly documented in the literature. They distort input choices, discourage outsourcing, harm exports, complicate administration (because the tax on inputs has to be allocated between taxable and exempt transactions) and encourage tax avoidance. Similarly, zero rates on domestically-consumed products involve additional administrative and compliance burdens that VATs have difficulty coping with. More importantly, perhaps, zero rates and exemptions for goods and services disproportionately consumed by lower-income groups are ill-targeted instruments to mitigate the VAT burden on them.

More fundamentally, VAT reform should proceed from the notion that a best-practice VAT is primarily intended to raise revenue, predictably and efficiently. VAT differs from excise taxes in that it is not intended to change people's behavior (relative prices should not change) and from the import duties in that it should not be used to support trade policy. It differs from the income tax in that it should not be used to influence the tax burden distribution or to stimulate industry through investment incentives. Under VAT, the goal should be revenue and revenue alone. That revenue can be used to finance programs, such as education and basic health care, that benefit those who pay the VAT.

Base-broadening should increase revenue and make it easier to administer the VAT. The abolition of complicated design differentiations would reduce the influence exerted by legal opinions and interest groups, thus increasing the amount of administrative resources available for monitoring the compliance with the VAT. Generally, a fairly high threshold of, say, the equivalent of US $\$ 100,000$, should minimize the VAT burden on basic unprocessed foodstuffs that figure importantly in the household budgets of the poor, if combined with a general exemption of the agricultural sector (with an option to be taxed) in countries where this sector is dominated by smallholdings. If this is politically unacceptable, an exemption (not zero rate) could be permitted in addition for a limited number of basic, unprocessed foodstuffs, specifically enumerated in the law. 


\section{Acknowledgement}

Thanks are due to Leon Bettendorf, Pierre-Pascal Gendron, Cecil Morden and Judith Payne for their helpful comments on the draft of this paper.

\section{References}

Baunsgaard, T., and M. Keen (2010), Tax revenue and (or?) trade liberalization, Journal of Public Economics 94(9-10), 563-577.

Bettendorf, L.J.B., and S. Cnossen (2014), The long shadow of the EU's Common Directive, FinanzArchiv (forthcoming).

Cnossen, S. (2003), Is the VAT’s Sixth Directive becoming an anachronism? European Taxation 43(12), 434442.

Cnossen, S. (2004), VAT in South Africa: what kind of rate structure? International VAT Monitor 15, 19-24.

Ebrill, L., M. Keen, J-P. Bodin and V. Summers (2001), The Modern VAT, Washington DC: International Monetary Fund.

Fenochietto, R., and C. Pessino (2013), Understanding countries’ tax effort, IMF Working Paper WP/13/244.

Go, D.S., M. Kearney, S. Robinson and K. Thierfelder (2005), An analysis of South Africa's value added tax, World Bank Policy Research Paper 3671.

International Monetary Fund (2005), Uganda: Fifth Review under the Three-Year Arrangement under the Poverty Reduction and Growth Facility, Request for Waiver of Performance Criterion and Extension of Arrangement, IMF Country Report 05/306.

Katz Commission (1994), Commission of Inquiry into Certain Aspects of the Tax Structure of South Africa, Interim Report (1 and 3), Pretoria: Government Printer.

Keen, M. (2008), VAT, tariffs and withholding: border taxes and informality in developing countries, Journal of Public Economics 92(10-11), 1892-1906.

Keen, M. (2009), What do (and don't) we know about the value added tax? A review of Richard M. Bird and Pierre-Pascal Gendron's The VAT in Developing and Transitional Countries, Journal of Economic Literature 47(1), 159-170.

Keen, M. (2013), The anatomy of the VAT, National Tax Journal 66(2), 423-446.

Keen, M., and M. Mansour (2010), Revenue mobilisation in sub-Saharan Africa: challenges from globalisation I - trade reform, Development Policy Review 28(5), 553-571.

Kneller, R., M.F. Bleany and N. Gemmell (1999), Fiscal policy and economic growth: evidence from OECD countries, Journal of Public Economics 74(2), 171-190.

Martinez-Vazquez, J., and R.M. Bird (2011), Value-added tax: onward and upward? In E. Albi and J. MartinezVazquez (eds), The Elgar Guide to Tax Systems, Cheltenham, UK: Edward Elgar.

Moser, K. (2011), Revenue Data for IMF Member Countries as of 2011, Washington DC: Fiscal Affairs Department, International Monetary Fund.

Mugoya, P.K.D. (1998), Equity and VAT in Tanzania, African Journal of Finance and Management 7(1), 2232. 
Musgrave, R.A. (1969), Fiscal Systems, New Haven, US: Yale University Press.

National Treasury (2011), The VAT Treatment of Merit Goods and Services, Pretoria: National Treasury of South Africa, Document T16/05.

OECD (2012), Consumption Tax Trends 2011: VAT/GST and Excise Rates, Trends and Administration Issues, Paris: OECD Publishing.

Rodrik, D. (2014), An African growth miracle? NBER Working Paper 20188.

WoldeMariam, A. (2010), VAT Revenue Productivity for Selected Fund Member Countries, Washington DC: Fiscal Affairs Department, International Monetary Fund. 
Table 1. Tax Ratios, Tax Capacity and Tax Effort in African VAT Countries

\begin{tabular}{|c|c|c|c|c|}
\hline Country & $\begin{array}{l}\text { Tax ratio } \\
(\%)\end{array}$ & $\begin{array}{l}\text { Tax capacity } \\
\text { (\%) }\end{array}$ & Tax effort & $\begin{array}{l}\text { Other countries whose tax effort is } \\
\text { likely to be low/medium/high }\end{array}$ \\
\hline \multicolumn{5}{|c|}{ Low tax effort ( 0.67 or lower) } \\
\hline Guinea-Bissau & 9.0 & 27.4 & 0.33 & Central African Republic, Chad, DR \\
\hline Egypt & 16.7 & 35.9 & 0.46 & Congo, Rwanda, Sierra Leone, Sudan \\
\hline Algeria & 16.8 & 36.1 & 0.47 & \\
\hline Cameroon & 12.8 & 24.4 & 0.52 & \\
\hline Ghana & 16.9 & 32.1 & 0.52 & \\
\hline Gambia, The & 12.3 & 21.1 & 0.58 & \\
\hline Tanzania & 15.3 & 26.0 & 0.59 & \\
\hline Madagascar & 10.8 & 17.0 & 0.63 & \\
\hline Uganda & 12.4 & 19.1 & 0.65 & \\
\hline Ethiopia & 11.3 & 17.0 & 0.66 & \\
\hline Burkina Faso & 14.1 & 21.0 & 0.67 & \\
\hline \multicolumn{5}{|c|}{ Medium tax effort $(0.68-0.80)$} \\
\hline Congo, Rep. of & 27.2 & 38.5 & 0.71 & Benin, Botswana, Burundi, Cabo Verde, \\
\hline Niger & 13.5 & 18.8 & 0.72 & Côte d'Ivoire, Djibouti, Equatorial \\
\hline South Africa & 27.8 & 38.2 & 0.73 & Guinea, Gabon, Mauritania, Mauritius \\
\hline Tunisia & 25.5 & 34.6 & 0.74 & \\
\hline Senegal & 19.4 & 26.0 & 0.75 & \\
\hline Kenya & 20.7 & 27.1 & 0.76 & \\
\hline Mali & 14.4 & 18.8 & 0.77 & \\
\hline Guinea & 14.8 & 18.9 & 0.78 & \\
\hline Togo & 15.9 & 20.1 & 0.79 & \\
\hline Morocco & 24.3 & 30.4 & 0.80 & \\
\hline \multicolumn{5}{|c|}{ High tax effort ( 0.81 or higher) } \\
\hline Mozambique & 18.2 & 21.4 & 0.85 & Lesotho, Seychelles, Swaziland, \\
\hline Namibia & 25.3 & 27.8 & 0.91 & Zimbabwe \\
\hline Malawi & 23.3 & 23.8 & 0.98 & \\
\hline Zambia & 16.6 & 17.0 & 0.98 & \\
\hline
\end{tabular}

Source: Fenochietto and Pessino (2013, appendix 2) and the author's assessment based on the economic and institutional indicators used by Fenochietto and Pessino.

Note: Countries are ranked in ascending order of tax effort. 


\begin{tabular}{|c|c|c|c|c|c|c|c|c|c|}
\hline \multirow{2}{*}{\multicolumn{2}{|c|}{$\begin{array}{l}\text { Regions, countries and } \\
\text { year VAT introduced }\end{array}$}} & \multirow{3}{*}{$\begin{array}{l}\text { Standard } \\
\text { rate }(\%)^{a}\end{array}$} & \multicolumn{3}{|c|}{ VAT systems } & \multicolumn{4}{|c|}{ VAT revenue performance } \\
\hline & & & Lower rate & Non-standard & Thresholds & VAT as \% of & VAT & & Year of data \\
\hline \multicolumn{9}{|c|}{ Southern African Development Community (SADC) } & \\
\hline \multicolumn{10}{|c|}{ 1. Southern African Customs Union (SACU) } \\
\hline Botswana & 2002 & 12 & 0 (various) & Few & 57,000 & 23.2 & 0.61 & 0.38 & 2010 \\
\hline Lesotho & 2003 & 14 & 0 (various); 5 (few) & Some & 71,000 & 22.4 & 0.48 & 0.62 & 2010 \\
\hline Namibia & 2000 & 15 & 0 (many) & Few & 20,000 & 21.7 & 0.56 & 0.41 & 2010 \\
\hline South Africa & 1991 & 14 & 0 (various) & Few & 93,000 & 24.8 & 0.67 & 0.49 & 2010 \\
\hline Swaziland & 2012 & 14 & 0 (various) & Some & 50,000 & 18.3 &.. & 0.47 & $2012^{*}$ \\
\hline \multicolumn{10}{|c|}{ 2. Other SADC countries } \\
\hline Congo, $\mathrm{DR}^{\mathrm{f}}$ & 2012 & 16 & - & Many & 87,000 & .. & .. & .. & .. \\
\hline Madagascar & 1994 & 20 & - & Many & 100,000 & 13.9 & 0.15 & 0.12 & 2006 \\
\hline Malawi & 2002 & 16.5 & 0 (many) & Many & 24,000 & 35.4 & 0.34 & 0.34 & 2006 \\
\hline Mauritius & 1998 & 15 & 0 (various) & Various & 133,000 & 38.0 & 0.58 & 0.47 & 2010 \\
\hline Mozambique & 1999 & 17 & 0 (various) & Many & 84,000 & 39.4 & 0.35 & 0.31 & 2006 \\
\hline Seychelles & 2013 & 15 & 0 (some) & Many & 245,000 & 30.6 & 0.87 & 0.64 & 2013* \\
\hline Zambia & 1995 & 16 & 0 (many) & Many & 145,000 & 30.6 & 0.34 & 0.24 & 2009 \\
\hline Zimbabwe & 2004 & 15 & 0 (various) & Some & 60,000 & 33.3 & 0.64 & 0.62 & 2010 \\
\hline \multicolumn{10}{|c|}{ East African Community (EAC) } \\
\hline Burundi $^{f}$ & 2009 & 18 & 0 (various) & Various & 65,000 & .. &.. & .. & .. \\
\hline Kenya & 1990 & 16 & 0 (water) & Various & 57,000 & 28.7 & 0.39 & 0.35 & 2010 \\
\hline Rwanda & 2001 & 18 & - & Many & 31,000 & 36.3 & 0.27 & 0.24 & 2006 \\
\hline Tanzania $^{\mathrm{g}}$ & 1998 & 18 & 0 (various) & Many & 25,000 & 30.2 & 0.31 & 0.25 & 2010 \\
\hline Uganda & 1996 & 18 & 0 (various); 5 (houses) & Many & 20,000 & 28.8 & 0.20 & 0.19 & 2010 \\
\hline \multicolumn{10}{|c|}{ Communauté Économique et Monétaire de l’Afrique Central (CEMAC) } \\
\hline Cameroon & 1999 & 19.25 & - & Various & 102,000 & 37.1 & 0.30 & 0.24 & 2006 \\
\hline Centr Afr Rep & 2001 & 18 & $5(\mathrm{few})$ & Many & 61,000 & 31.2 & 0.14 & 0.14 & 2009 \\
\hline Chad & 2000 & 18 & - & Many & $61 / 40,000$ & 23.2 & 0.14 & 0.11 & 2006 \\
\hline Congo, Rep. of & 1997 & 18.9 & 0 (wood); 5 (some) & Many & 81,000 & 33.3 & 0.31 & 0.12 & 2005 \\
\hline Equat. Guinea & 2005 & 15 & 0 (medicines); 6 (some) & Many & 162,000 & 3.6 & 0.15 & 0.05 & 2009 \\
\hline Gabon & 1995 & 18 & 5 (cement); 10 (various) & Many & 122,000 & 6.8 & 0.21 & 0.09 & 2006 \\
\hline \multicolumn{10}{|c|}{ Economic Community of West African States (ECOWAS) } \\
\hline \multicolumn{10}{|c|}{ 1. Union Économique et Monétaire Ouest Africaine (UEMOA) } \\
\hline Benin & 1980 & 18 & - & Many & $81 / 30,000$ & 41.2 & 0.45 & 0.39 & 2010 \\
\hline Burkina Faso & 1993 & 18 & - & Many & $101 / 30,000$ & 34.9 & 0.28 & 0.24 & 2006 \\
\hline Côte d'Ivoire & 1960 & 18 & 7.2 (few); 9 (some) & Many & $101 / 61,000$ & 8.4 & 0.11 & 0.09 & 2010 \\
\hline Guinea-Bissau & 1997 & 16.2 & - & Various &.. & 29.0 & .. & 0.18 & 2006 \\
\hline Mali & 1991 & 18 & - & Many & $101 / 61,000$ & 39.3 & 0.52 & 0.37 & 2007 \\
\hline Niger & 1986 & 19 & - & Many & $61 / 20,000$ & 17.6 & 0.11 & 0.09 & 2005 \\
\hline Senegal & 1980 & 18 & 10 (tourism) & Various & $101 / 50,000$ & 42.1 & 0.55 & 0.44 & 2006 \\
\hline Togo & 1995 & 18 & - & Various & $61 / 20,000$ & 44.3 & 0.43 & 0.39 & 2010 \\
\hline \multicolumn{10}{|c|}{ 2. West African Monetary Zone (WAMZ) } \\
\hline Cabo Verde & 2004 & 15 & 0 (various) & Various & 2,000 & 37.0 & 0.65 & 0.53 & 2006 \\
\hline Gambia & 2013 & 15 & 0 (various) & Various & 27,000 & .. & .. & .. &.. \\
\hline Ghana & 1998 & 15 & - & Many & 33,000 & 30.1 & 0.39 & 0.27 & 2010 \\
\hline Guinea & 1996 & 18 & - & Various & 71,000 & 36.3 & 0.25 & 0.21 & 2006 \\
\hline Sierra Leone & 2009 & 15 & - & Many & 46,000 & 20.2 &.. & 0.15 & 2011 \\
\hline \multicolumn{10}{|c|}{ Union Maghreb Arabe (UMA) } \\
\hline Algeria & 1992 & 17 & 7 (many) & Some & 2,000 & 12.3 & 0.51 & 0.25 & 2009 \\
\hline Mauritania & 1995 & 14 & - & Various & $20 / 10,000$ & 31.4 & 0.52 & 0.39 & 2006 \\
\hline Morocco & 1986 & 20 & 7 (some); $10 \& 14$ (var) & Various & $59 / 237,000$ & 30.2 & 0.64 & 0.43 & 2010 \\
\hline Tunisia & 1988 & 18 & 6 (various); 12 (various) & Various & 61,000 & 24.3 & 0.50 & 0.36 & 2009 \\
\hline \multicolumn{10}{|c|}{ Intergovernmental Authority on Development (IGAD) and Egypt } \\
\hline Djibouti & 2009 & 7 & - & Few & 278,000 &.. &.. & .. &.. \\
\hline Egypt & 1991 & 10 & 5 (various) & Many & $8 / 21,000$ & 20.6 & 0.40 & 0.32 & 2006 \\
\hline Ethiopia & 2003 & 15 & - & Various & 27,000 & 14.1 & 0.11 & 0.11 & 2010 \\
\hline Sudan & 2000 & 17 & - & Various & 23,000 &.. &.. &.. &.. \\
\hline
\end{tabular}

Source: Author's compilation on the basis of country legislation and information culled from IBFD on line, PwC, Helping You Navigate Africa's VAT Landscape, April 2014, and similar publications. Most information is from secondary sources and some may be incomplete or out-of-date. Revenue data are from Moser (2011) but IMF country reports for 2011 and later years.

${ }^{2}$ Higher-than-standard VAT rates are unusual in Africa. Swaziland taxes tobacco products and alcoholic beverages at $25 \%$, Côte d'Ivoire taxes cigarettes at $21.31 \%$ at the wholesale stage but does not tax cigarettes sold at retail, Mauritania taxes fuel and telecommunications at $18 \%$ and Sudan taxes telecommunication services at $30 \%$. Exceptionally, Egypt imposes multiple higher rates of $15 \%, 20 \%$ and $30 \%$ on a wide range of products regarded as less essential.

${ }^{\mathrm{b}}$ Non-standard exemptions are all exemptions other than hospital and medical care (including ambulance services), dental care, education, charitable work, non-commercial activities of non-profit-making organizations, postal services, rental and occupation or sale of used residential property, cultural services, financial services, insurance and reinsurance, gambling, and 'out-of-scope' governments, which are exempted by all countries except the SACU countries, as noted in footnote 12 . The coverage of the non-standard exemptions is denoted by 'few' (some enumerated basic foodstuffs and public transportation), 'some' (more food items and some public utilities), 'various' (most unprocessed foods, agricultural inputs, medical goods, newspapers and utilities) and 'many' (all unprocessed foods, agricultural inputs, medical goods, utilities, print and fuel); details can be found in tables $3 \mathrm{~A}$ and $3 \mathrm{~B}$.

${ }^{c}$ Thresholds in local currencies have been converted into US\$ using the universal currency converter. Figures have been rounded to the nearest US\$1,000. Double thresholds mean that countries have different thresholds for manufacturing vs. trade (Morocco, Egypt) or for goods and services.

${ }^{\mathrm{d}}$ VAT C-efficiency is defined as actual VAT revenue as a proportion of potential VAT revenue calculated by applying the standard rate to total final consumption (except government).

EVT productivity is defined as actual VAT revenue as a percentage of GDP divided by the standard VAT rate.

${ }^{f}$ Also a member of CEMAC

${ }^{\mathrm{g}}$ Also a member of SADC.

* Provisional. 


\begin{tabular}{|c|c|c|c|c|c|c|c|}
\hline $\begin{array}{l}\text { Regions and } \\
\text { countries }\end{array}$ & $\begin{array}{l}\text { Unprocessed } \\
\text { foodstuffs }\end{array}$ & $\begin{array}{l}\text { Agricultural } \\
\text { inputs }\end{array}$ & $\begin{array}{l}\text { Medical } \\
\text { supplies }\end{array}$ & Utilities & Print & Fuel & Other important items \\
\hline \multicolumn{8}{|c|}{ Southern African Development Community (SADC) } \\
\hline \multicolumn{8}{|c|}{ 1. Southern African Customs Union (SACU) } \\
\hline Botswana & & & $\mathrm{V}$ & $\checkmark$ & & & \\
\hline Lesotho & & & & $\checkmark$ & & & low-income housing \\
\hline Namibia & & & & $\checkmark$ & & & \\
\hline South Africa & & & & $\checkmark$ & & & \\
\hline Swaziland & & & & $v^{*}$ & & & gambling \\
\hline \multicolumn{8}{|c|}{ 2. Other SADC countries } \\
\hline Congo, DR & $v^{*}$ & V & $v^{*}$ & $\checkmark$ & $\sqrt{ }$ & & admissions, supplies for extractive industries, art works \\
\hline Madagascar & $v$ & $\mathrm{v}^{*}$ & $v^{*}$ & $v$ & $v^{*}$ & & fabrics, solar panels \\
\hline Malawi & $v$ & $v$ & $v^{*}$ & $\checkmark$ & $\mathrm{v}^{*}$ & & gambling, admissions \\
\hline Mauritius & v & v & $v^{*}$ & $v$ & $v$ & & gambling, art works \\
\hline Mozambique & v & V & $v^{*}$ & & $\checkmark$ & & gambling, bicycles, garbage removal \\
\hline Seychelles & $v$ & & v & & & $v$ & \\
\hline Zambia & v & v & $\mathrm{V}$ & $\checkmark$ & $\mathrm{v}^{*}$ & $v$ & gambling, transport \\
\hline Zimbabwe & & & & v & & $\mathrm{v}^{*}$ & \\
\hline \multicolumn{8}{|c|}{ East African Community (EAC) } \\
\hline Burundi & $\mathrm{v}^{*}$ & V & $\mathrm{V}^{*}$ & $v$ & & & \\
\hline Kenya & $v$ & v & v & $v$ & & $\mathrm{v}^{*}$ & plant and machinery \\
\hline Rwanda & $\mathrm{v}^{*}$ & $\mathrm{~V}^{*}$ & v & $v$ & $v$ & $\mathrm{v}^{*}$ & tourism, hotels, machinery, raw materials \\
\hline Tanzania & $v^{*}$ & $v^{*}$ & $\mathrm{v}$ & $v$ & $v^{*}$ & $\mathrm{v}^{*}$ & gambling, tourism, yarn, energy-saving appliances \\
\hline Uganda & $v^{*}$ & $\mathrm{~V}^{*}$ & $\mathrm{~V}^{*}$ & $\checkmark$ & & $\mathrm{v}^{*}$ & gambling, tourism \\
\hline \multicolumn{8}{|c|}{ Communauté Économique et Monétaire de l'Afrique Central (CEMAC) } \\
\hline Cameroon & $v^{-}$ & $v^{*}$ & $\mathrm{~V}$ & $\checkmark$ & $\checkmark$ & & wood, energy-saving equipment, computers \\
\hline Centr Afr Rep & $v^{-}$ & & $v^{*}$ & $v$ & v & & \\
\hline Chad & $v^{*}$ & & $\mathrm{v}$ & $v$ & v & & building materials, admissions, extractives \\
\hline Congo & $v^{*}$ & V & $\mathrm{v}$ & & v & & entertainment, culture \\
\hline Equat. Guinea & $v^{*}$ & $v^{*}$ & $v$ & & $\checkmark$ & & culture, imported capital equipment, mining \\
\hline Gabon & $v^{*}$ & $\mathrm{~V}^{*}$ & $\mathrm{~V}$ & & v & & tourism, inputs for extractive industries \\
\hline
\end{tabular}

Benin
Burkina Faso
Côte d'Ivoire
Guinea-Bissau
Mali
Niger
Senegal
Togo

Cabo Verde

Gambia

Ghana

Guinea

Sierra Leone

Algeria

Mauritania

Morocco

Tunisia

$v^{*}$
$v^{*}$
$v^{*}$
$V^{*}$
$V^{*}$
$V^{*}$
$v^{*}$

V

$\checkmark$

$v^{*}$

$\mathrm{V}^{*}$

$\mathrm{V}^{*}$
$\mathrm{~V}^{*}$
$\mathrm{v}$
$\mathrm{V}$
$\mathrm{v}^{-}$
$\mathrm{V}$
$\mathrm{V}^{-}$
$\mathrm{V}$ (retail)

$v$
$v^{*}$
$v^{*}$
$v^{*}$
$v^{*}$

Djibouti

Egypt

Ethiopia

Sudan

Source: See table 2 .

${ }^{a}$ The symbols $(\mathrm{V})$ should be interpreted as follows:

Economic Community of West African States (ECOWAS)

1. Union Économique et Monétaire Ouest Africaine (UEMOA)

$$
\text { v }
$$$$
\begin{array}{ll}
v & v \\
v & v \\
& v^{*}
\end{array}
$$$$
\begin{array}{ll}
v^{*} & v \\
v & v^{*}
\end{array}
$$$$
\checkmark \text { V* }
$$

2. West African Monetary Zone (WAMZ)

.

-Agricultural inputs: $v=$ feed, seed, fertilizer; $v^{*}=$ in addition, machinery and implements.

-Medical supplies: $\mathrm{V}=$ medicines and pharmaceutical products; $\mathrm{V}^{*}=$ in addition, medical equipment.

-Utilities (water, electricity, natural gas, postal services, telecommunications, public transportation): $\vee=$ one or two items; $\vee^{*}=m o r e$ than two items.

-Print: $\mathrm{V}=$ newspapers, books and periodicals; $\mathrm{V}^{*}=$ most published materials.

-Fuel: $\mathrm{V}=$ kerosene; $\mathrm{V}^{*}=$ all petroleum products.

NB. Standard exemptions are not shown, because they are found in all countries without a modern VAT. Standard exemptions include health care, education, social and cultural

services, immovable property (except if newly created), financial services and insurance, postal and broadcasting services, gambling, and 'out-of-scope' governments. See OECD (2012). 


\begin{tabular}{|c|c|c|c|c|c|c|c|}
\hline $\begin{array}{l}\text { Regions and } \\
\text { countries }\end{array}$ & $\begin{array}{l}\text { Unprocessed } \\
\text { foodstuffs }\end{array}$ & $\begin{array}{l}\text { Agricultural } \\
\text { inputs }\end{array}$ & $\begin{array}{l}\text { Medical } \\
\text { supplies }\end{array}$ & Utilities & Print & Fuel & Other important items \\
\hline \multicolumn{8}{|c|}{ Southern African Development Community (SADC) } \\
\hline Botswana & $v^{-}$ & $v^{*}$ & & & & $\mathrm{~V}^{*}$ & \\
\hline Lesotho & $v^{-}$ & $v$ & & $v(5)$ & & $\mathrm{v}$ & building materials, commercial transportation \\
\hline Namibia & $v^{-}$ & & v & v & & $\mathrm{v}^{*}$ & residential property, telecommunications \\
\hline South Africa & $v^{-}$ & & & & & $v^{*}$ & housing subsidies \\
\hline Swaziland & $v^{-}$ & $v$ & v & & v & $v$ & \\
\hline \multicolumn{8}{|c|}{ 2. Other SADC countries } \\
\hline \multicolumn{8}{|l|}{ Congo, DR } \\
\hline \multicolumn{8}{|l|}{ Madagascar } \\
\hline Malawi & $v^{-}$ & $v^{*}$ & $v$ & $v$ & $\mathrm{~V}$ & & building materials, machinery, trucks, tourism \\
\hline Mauritius & 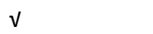 & $\sqrt{ }$ & & v & $\mathrm{V}^{*}$ & & irrigation \\
\hline \multicolumn{8}{|l|}{ Mozambique } \\
\hline Seychelles & v & & & v & & & tourism \\
\hline Zambia & $\mathrm{v}$ & $v^{*}$ & $v^{*}$ & & v & & tourism, energy-saving appliances \\
\hline Zimbabwe & $\mathrm{v}$ & $v^{*}$ & $v^{*}$ & & & & \\
\hline \multicolumn{8}{|c|}{ East African Community (EAC) } \\
\hline Burundi & v & & & & & & \\
\hline Kenya & & & & $\mathrm{V}$ & & & \\
\hline \multicolumn{8}{|l|}{ Rwanda } \\
\hline Tanzania & $v^{-}$ & $v$ & $v^{*}$ & & & & imported capital goods, water pumps, software \\
\hline Uganda & $v^{*}$ & $v^{*}$ & $v^{*}$ & v & & $v^{*}$ & housing (5) \\
\hline \multicolumn{8}{|c|}{ Communauté Économique et Monétaire de l’Afrique Central (CEMAC) } \\
\hline \multicolumn{8}{|l|}{ Cameroon } \\
\hline \multicolumn{7}{|l|}{ Chad } & \\
\hline Congo, Rep. of & v & & & & & $v^{*}(5)$ & local wood, cement (5) \\
\hline Equat. Guinea & $v^{-}(6)$ & $v^{*}$ & $v$ & & $\checkmark(6)$ & & imported capital equipment \\
\hline Gabon & $v^{-}(10)$ & & $v$ & & & & imported capital equipment, cement (5) \\
\hline \multicolumn{2}{|c|}{$\begin{array}{l}\text { Economic Community of West African States (ECOWAS) } \\
\text { 1. Union Économique et Monétaire Ouest Africaine (UEMOA) }\end{array}$} & & & & & & \\
\hline Benin & $v^{-}$ & & & & & & \\
\hline \multicolumn{8}{|l|}{ Burkina Faso } \\
\hline Côte d'Ivoire & $v^{-}(9)$ & & $\checkmark(7.2)$ & & $v(7.2)$ & $v^{*}(9)$ & solar energy equipment \\
\hline \multicolumn{8}{|l|}{ Guinea-Bissau } \\
\hline \multicolumn{8}{|l|}{ Mali } \\
\hline \multicolumn{8}{|l|}{ Niger } \\
\hline Senegal & & & & & & & tourism (10) \\
\hline \multicolumn{8}{|l|}{ Togo } \\
\hline \multicolumn{8}{|c|}{ 2. West African Monetary Zone (WAMZ) } \\
\hline Cabo Verde & v & & v & & $v$ & & \\
\hline Gambia & $v$ & & & & & & \\
\hline Ghana & & & & & & & \\
\hline Guinea & & & & & & & \\
\hline Sierra Leone & & & & & & & \\
\hline & & & & Union & b Arabe & & \\
\hline Algeria & $v^{*}(7)$ & $\vee(7)$ & $v(7)$ & & $V(7)$ & $v^{*}(7)$ & entertainment, construction, handicraft (7) \\
\hline Mauritania & & & & & & & \\
\hline Morocco & $V(7 / 10 / 14)$ & $v$ & $v(7)$ & $v(14)$ & $V(7)$ & & hotels and restaurants, professions (10) \\
\hline Tunisia & $v$ & $\vee(6)$ & $v(6)$ & $v(6)$ & $V(12)$ & & hotels/restaurants, tourism, professions \\
\hline & & & Inte & nental Aut & Develo & D) and $\mathrm{E}$ & \\
\hline Djibouti & & & & & & & \\
\hline Egypt & $v^{-}(5)$ & $\vee(5)$ & $v(5)$ & & & & wood, gypsum (5) \\
\hline Ethiopia & & & & & & & \\
\hline Sudan & & & & & & & \\
\hline
\end{tabular}

Sudan

Source: See table 2

${ }^{a}$ Numbers in parentheses indicate the reduced rate. The symbols $(\mathrm{V})$ should be interpreted as follows:

-Unprocessed foodstuffs: $\mathrm{V}^{-}=$limited number of enumerated items; $\mathrm{V}=$ large number of items; $\mathrm{V}^{*}=$ all unprocessed foodstuffs.

-Agricultural inputs: $V=$ feed, seed, fertilizer; $V^{*}=$ in addition, machinery and implements.

-Medical supplies: $v=$ medicines and pharmaceutical products; $\mathrm{V}^{*}=$ in addition, medical equipment.

-Utilities (water, electricity, natural gas, postal services, telecommunications, public transportation): $\vee=$ one or two items; $\vee^{*}=m o r e$ than two items.

-Print: $V=$ newspapers, books and periodicals; $V^{*}=$ most published materials.

-Fuel: $\mathrm{V}=$ kerosene; $\mathrm{V}^{*}=$ all petroleum products. 


\begin{tabular}{|c|c|c|c|c|c|c|}
\hline \multirow[t]{3}{*}{ Product } & \multicolumn{5}{|c|}{ Expenditure groups and annual averages within groups } & \multirow{3}{*}{ Tota } \\
\hline & Very low & Low & Middle & High & Very high & \\
\hline & $\mathrm{R} 5,314$ & $\mathrm{R} 10,052$ & $\mathrm{R} 17,340$ & $\mathrm{R} 35,707$ & $\mathrm{R} 139,243$ & \\
\hline \multicolumn{7}{|c|}{ A. Percentage of VAT savings accruing to different expenditure groups } \\
\hline \multicolumn{7}{|c|}{ 1. Zero-rated goods and services } \\
\hline \multicolumn{7}{|l|}{ Corn, rice, grains, potatoes } \\
\hline -maize & 20.8 & 18.3 & 19.2 & 12.4 & 29.3 & 100.0 \\
\hline -maize meal & 19.6 & 21.2 & 31.0 & 17.7 & 10.6 & 100.0 \\
\hline -bread flour & 19.1 & 22.2 & 31.4 & 17.6 & 9.7 & 100.0 \\
\hline -rice & 10.5 & 14.7 & 29.0 & 25.2 & 20.6 & 100.0 \\
\hline -maize rice & 14.7 & 18.2 & 29.6 & 21.3 & 16.2 & 100.0 \\
\hline -brown bread & 9.8 & 14.4 & 31.0 & 26.2 & 18.6 & 100.0 \\
\hline -potatoes & 13.9 & 14.8 & 26.7 & 24.7 & 20.0 & 100.0 \\
\hline \multicolumn{7}{|l|}{ Dairy products } \\
\hline -fresh milk & 5.1 & 7.6 & 20.2 & 26.5 & 40.6 & 100.0 \\
\hline -sour milk & 10.4 & 13.8 & 29.1 & 26.7 & 20.0 & 100.0 \\
\hline -milk powder & 9.6 & 14.5 & 31.3 & 26.1 & 18.6 & 100.0 \\
\hline -UHT milk & 8.1 & 9.9 & 18.9 & 23.0 & 40.0 & 100.0 \\
\hline -eggs & 7.9 & 11.5 & 26.6 & 26.0 & 28.0 & 100.0 \\
\hline \multicolumn{7}{|l|}{ Vegetables } \\
\hline -tomatoes & 10.9 & 13.7 & 27.3 & 24.6 & 23.6 & 100.0 \\
\hline -lettuce & 0.7 & 1.6 & 6.9 & 21.1 & 69.6 & 100.0 \\
\hline -apples & 0.3 & 3.0 & 9.5 & 24.1 & 63.1 & 100.0 \\
\hline -bananas & 2.4 & 5.6 & 12.1 & 24.0 & 55.8 & 100.0 \\
\hline -oranges & 1.0 & 2.0 & 10.2 & 28.3 & 58.5 & 100.0 \\
\hline \multicolumn{7}{|l|}{ Other } \\
\hline -cooking oils & 5.6 & 7.5 & 20.6 & 29.1 & 37.2 & 100.0 \\
\hline -paraffin (kerosene) & 4.6 & 7.5 & 20.6 & 26.3 & 41.0 & 100.0 \\
\hline \multicolumn{7}{|c|}{ 2. Exempt goods and services } \\
\hline \multicolumn{7}{|l|}{ Public transport } \\
\hline -buses & 0.0 & 0.0 & 0.3 & 10.7 & 89.0 & 100.0 \\
\hline -trains & 0.1 & 0.1 & 2.7 & 13.7 & 83.4 & 100.0 \\
\hline -metered cabs & 0.2 & 0.1 & 2.5 & 9.8 & 87.5 & 100.0 \\
\hline -other & 0.0 & 0.0 & 0.0 & 1.4 & 98.6 & 100.0 \\
\hline \multicolumn{7}{|l|}{ Education } \\
\hline -pre-primary & 0.4 & 1.0 & 5.2 & 17.6 & 75.8 & 100.0 \\
\hline -public & 0.3 & 1.5 & 7.3 & 22.8 & 68.1 & 100.0 \\
\hline -private & 0.0 & 0.0 & 0.1 & 5.1 & 94.8 & 100.0 \\
\hline -teacher training & 0.3 & 1.2 & 3.6 & 9.6 & 85.2 & 100.0 \\
\hline -universities & 0.9 & 3.3 & 11.5 & 27.4 & 56.9 & 100.0 \\
\hline \multicolumn{7}{|c|}{ B. Percentage of VAT paid by different expenditure groups on various goods and services that are standard-rated } \\
\hline \multicolumn{7}{|l|}{ Public utilities } \\
\hline -water & 2.8 & 4.3 & 12.7 & 22.4 & 57.8 & 100.0 \\
\hline -electricity & 1.1 & 2.5 & 10.8 & 25.3 & 60.3 & 100.0 \\
\hline \multicolumn{7}{|l|}{ Medicines } \\
\hline -with prescription & 3.5 & 5.9 & 18.9 & 28.6 & 43.1 & 100.0 \\
\hline -with prescription not covered by medical aid & 0.0 & 0.1 & 1.2 & 9.6 & 89.1 & 100.0 \\
\hline -without prescription & 3.3 & 8.3 & 23.1 & 31.2 & 34.2 & 100.0 \\
\hline -non-medical aid without prescription & 0.2 & 0.2 & 1.4 & 8.3 & 89.9 & 100.0 \\
\hline \multicolumn{7}{|l|}{ Health services } \\
\hline -flat fee & 3.6 & 1.8 & 3.6 & 6.9 & 84.1 & 100.0 \\
\hline -not covered by medical aid & 1.8 & 4.5 & 14.4 & 22.0 & 57.4 & 100.0 \\
\hline -doctors, dentists, etc. & 1.5 & 2.5 & 8.8 & 15.6 & 71.5 & 100.0 \\
\hline \multicolumn{7}{|l|}{ Reading material } \\
\hline -textbooks & 0.1 & 1.0 & 8.8 & 25.3 & 64.8 & 100.0 \\
\hline -newspapers & 1.7 & 3.6 & 11.7 & 24.6 & 58.3 & 100.0 \\
\hline -magazines & 9.0 & 8.1 & 23.7 & 32.1 & 27.1 & 100.0 \\
\hline -books & 6.3 & 8.6 & 19.9 & 24.5 & 40.7 & 100.0 \\
\hline
\end{tabular}

Source: National Treasury, 2011, tables 31 and 32. 


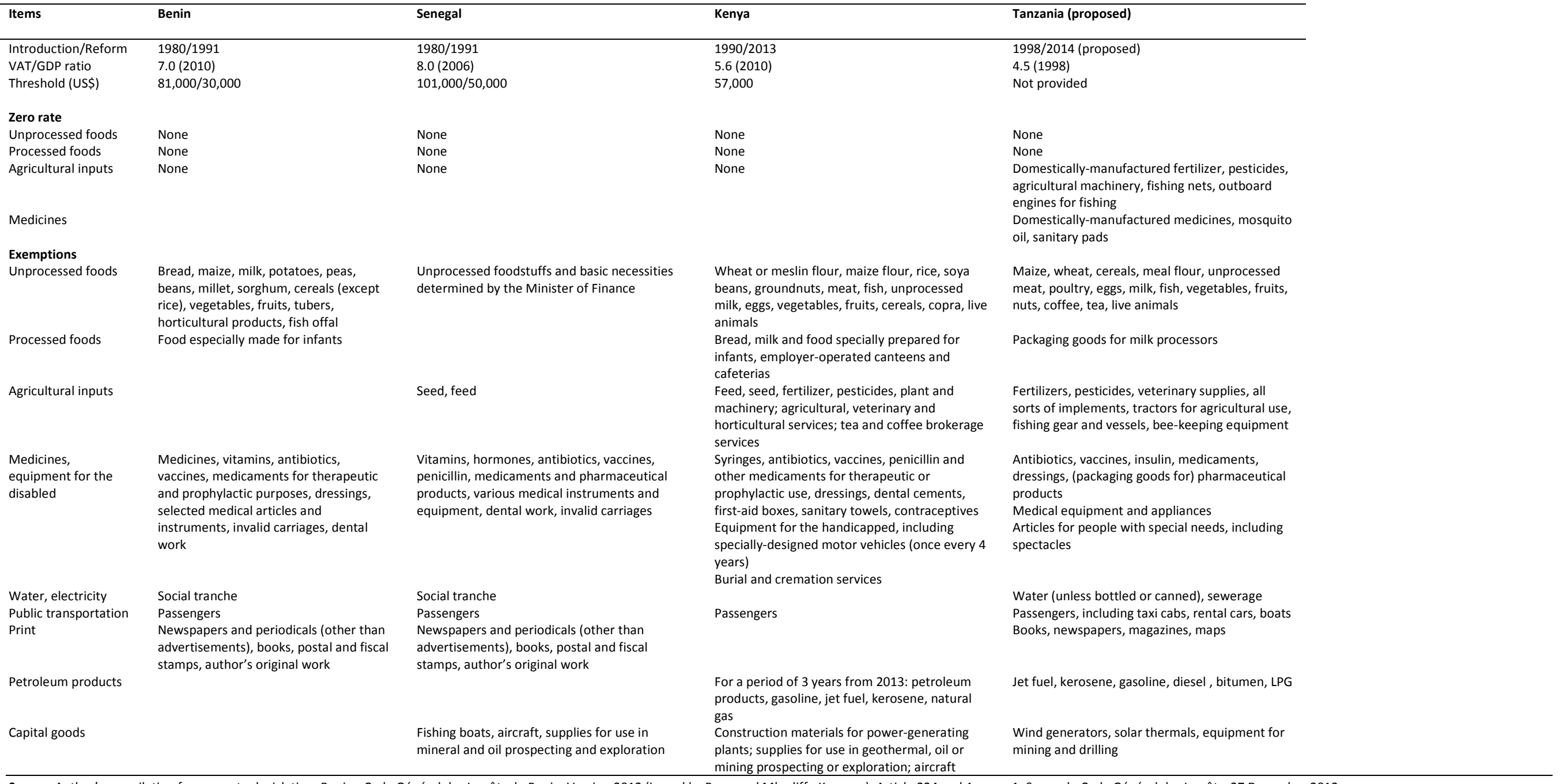

Source: Author's compilation from country legislation: Benin - Code Général des Impôts du Benin, Version 2012 (issued by Raymond Mbadiffo Kouamo), Article 224 and Annexe 1: Senegal - Code Général des Impôts, 27 December 2012,

Article 361; Kenya - Value Added Tax, First Schedule; Tanzania - The Value Added Tax Act, 2014, Special Bill Supplement No. 3, 12 May 2014, Jedwali. 


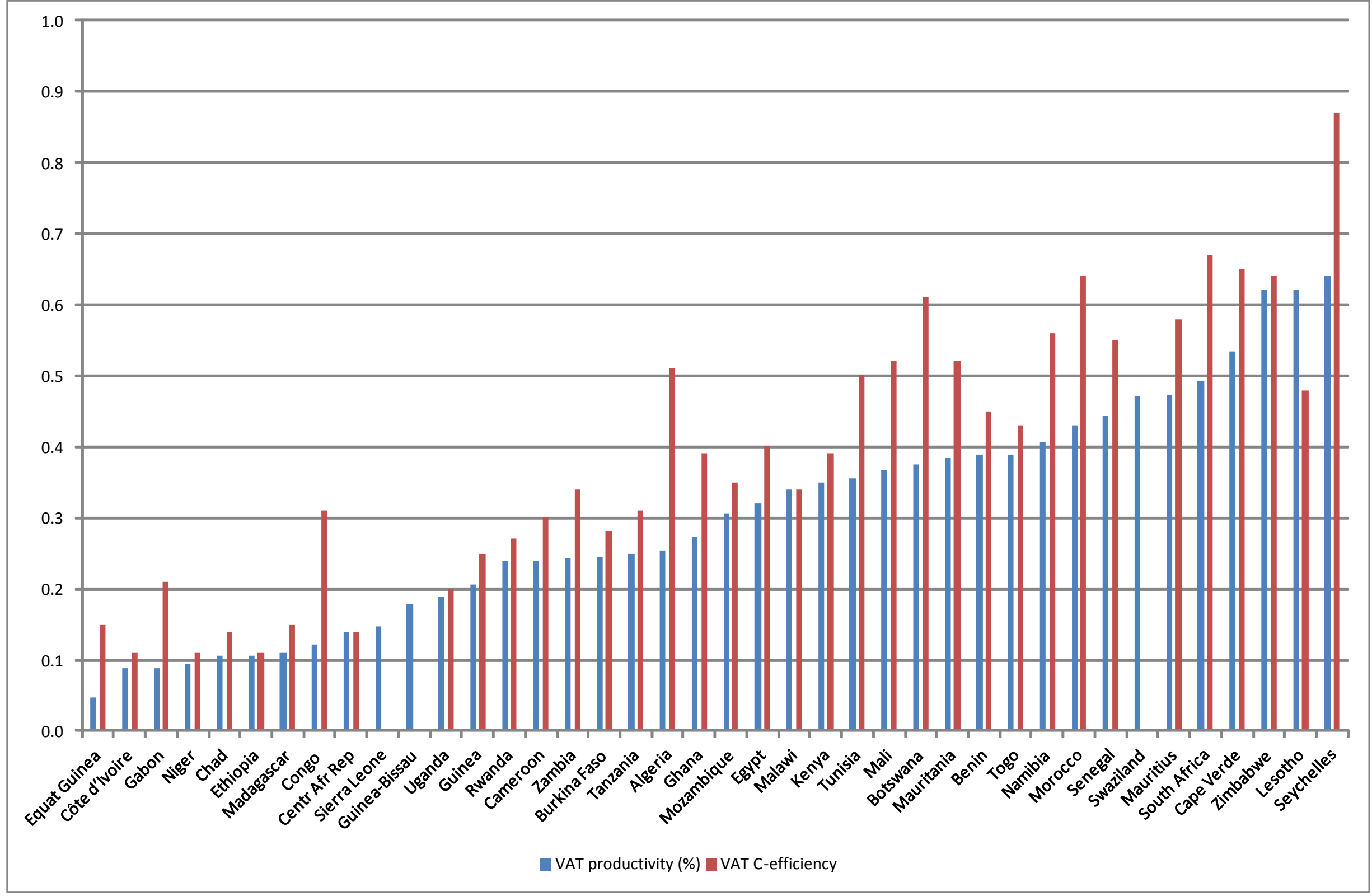

